\title{
The Effect of Debt, Liquidity and Corporate Tax Policy on Dividend Policy with Profitability as Intervening Variables in Trading Companies Listed on the Indonesia Stock Exchange for the 2014-2019
}

Period is profitability mediate policy dividends: Empirical Evidence on Emerging Market in Indonesia

\author{
Katryn Trie Wicak Ikhsani ${ }^{1}$, MF. Arrozi Adhikara ${ }^{2}$ \\ ${ }^{1,2}$ Esa Unggul University
}

\begin{abstract}
Study this aim for get Proof empirical is Policy Debt, Liquidity and Corporate Tax have an effect to Policy Dividend with Profitability as intervening variables in the company Trades listed on the IDX for the period 2014 to 2019. Research this using 16 companies Trades listed on the IDX from 2014 to 2019 with use purposive sampling method. Research data this analyzed with Analysis of Moment Structure (AMOS) method. Research results show that variable Policy Debt, Liquidity and Corporate Tax together take effect to Policy Dividends. Variable Policy Debt, Liquidity and Profitability take effect to Policy Dividends. Variable Policy Debt and Liquidity take effect to Profitability. Study this also finds that variable Profitability could mediate influence Policy Debt, Liquidity and Corporate Tax on Policy Dividends.
\end{abstract}

KEYWORDS: Corporate Tax, Debt, Dividend Policy, Liquidity, Profitability.

\section{INTRODUCTION}

Indonesia including as a developing country located in the ASIA region with growth great economy common in the capital market sector. Until September 21, 2020, IDX has write down as many as 55 companies recorded new to BEI. Amount company grow and experience increase recorded by 59\% of in 2019 (investasi.kontan.co.id). Growth issuers listed on the Indonesia Stock Exchange (IDX) are supported with the more big interest Public for save stock. All investors experience growth by $13 \%$ or becomes as many as 2.81 Million Capital Market Investors at the end 2019"

(mediainvestasi.kontan.co.id).

Ascension total listed company and increase number of investors per year no in accordance with total issuer who shared dividend his company. Phenomenon payment moderate dividend taking place in Indonesia has confirmed decrease based on acquisition information from the years before and some total issuer showing distribution dividend not enough from half or $50 \%$ of companies listed on the IDX. Company can use issue dividend for do significant growth and Performance Company to party outside or potential investors. In other words, the issue dividend can available news and data about the ability (skills and performance) of such a company good. In one the investor side, the company that shares dividend by consistent and relative big to be signal positive (Good News). And vice versa companies that don't consistent share dividend or occur drop dividend rated as news bad (Bad News). That is, without good prospects, the end only end with price negative stock.

Policy dividend determined with a number of factor that is regulation law, liquidity, need payment return debt company, limitations because contract loan (restriction in debt contract), rate expansion property (rate of asset expansion), rate profit, Tax Company. The factors that have used in study before the still experience inconsistency results as policy debt, liquidity, corporate tax and profitability intervening variables. Policy proxied debt with Debt to Equity Ratio that is a measurement that compares total debt with total equity. The more tall Debt to Equity Ratio show the more big total debt to total equity, will also show the more big dependency company to party outside so that level risk company the more big. Research conducted by (William et. al., 2019) and (Ginting, 2018) give conclusion that policy debt no take effect to policy dividends. However no in line with research conducted by (Prasetyo \& Sampurno, 2013) and (Mahesti et. al., 2013) which concludes that policy debt take effect to policy dividends. Variable liquidity be measured with current ratio that is compare assets fluent with debt smoothly. Sartono say that, influence liquidity unidirectional with policy dividend where the more big liquidity in a company so the more great ability company in pay dividends 


\section{International Journal of Current Science Research and Review}

ISSN: 2581-8341

Volume 05 Issue 02 February 2022

DOI: 10.47191/ijesrr/V5-i2-20, Impact Factor: 5.825

(Hasana et al., 2017) Research (Cahyani \& Badjra, 2017) state liquidity no take effect to policy dividends. Different with (Ano et al., 2014) which states liquidity take effect to policy dividends.

Corporate Tax or Tax Company is one variable that can be give bad influence or negative to payment Dividend Company. In fact, the tax that must be paid company could reduce Income Company as big as it and also cause drop part Income Company in distribution dividend to holder stock. Gayatri (2015) and Erviliana (2014) stated that Corporate Tax Ratio no take effect significant to Policy Dividends. However Rechman \& Takumi (2012) and Hardiningsih (2013) stated that Corporate Tax Ratio take effect significant to Policy Dividends. Profitability in study this use Return on Equity that is compare profit clean after tax with total equity. Profitability as indicator Performance Company and company skills so that they can produce profit based on metric certain at the level sales, assets, or capital in period certain (William et. al., 2019). (Officers \& Wiksuana, 2018) and (Monika \& Sudjarni, 2018) conclude that Return on Equity take effect significant to Policy Dividends. I Lord Bagus (2018) and Nadia (2015) stated that return on Equity no take effect to policy dividends.

Study this use object study company in the field trading quote news from cnbcindonesia.com that PT Matahari Department Store in rating third issuer who shared dividend with high total dividends. Whereas look conditions that occur moment this many PT Matahari store Closed department stores. This thing Becomes a sign ask why management of PT Matahari Department Store no more many withhold the profit for operational so that no many PT Matahari store Closed department stores. On the other hand PT Map Active superpower Tbk (MAPA) no share dividend for year 2018 book. Company decide acquisition profit or profit earned company during 2018 will playing more formerly for prioritized on development effort.

Contribution study is for develop influencing factors company trading in set policy dividend as well as give outlook to investors who will embed capital in the company trading with condition moment this where medium online business growing in Indonesia.

Purpose study is for study influence Policy Debt, Liquidity and Corporate Tax to Policy Dividend with profitability as intervention variable.

\section{THEORY AND HYPOTHESES DEVELOPMENT}

\section{Theory Policy Dividend}

Policy dividend is decision, method, or set way company in determine how many part from profit clean shared as dividend to holder stock and how much part from profit net reinvested as profit detained. Policy dividend important because two reason that is payment dividend will influence price stock and retained earnings is source the largest and most important addition to the company's capital for growth company. Influencing factors policy dividend that is characteristics company (size, profitability, opportunity growth and maturity); market characteristics (tax, protection investor law, privatization or public); as well as shape replacement payment dividends.

\section{Irrelevance Theory}

Something theory that states that policy dividend no have influence to Mark company and costs the capital. Company value only depending on the expected profit from assets no from separation profit Becomes dividend and profit detained. Theory this consider that policy dividend no bring impact anything for Mark Company. So, upgrade or drop dividend by company no will influence Mark Company.

\section{The Bird in Hand Theory}

Theory this state that own capital cost company will go up if percentage profit paid to holder share in cash form or DPR (Dividend Payout Ratio) is low, because investors are more like accept dividend than capital gains (Capital Gains). Investors view profit dividend (dividend yield) more certain than capital gains (capital gains yield).

\section{Tax Preference Theory}

Theory this state that the holders share more choose payment low dividend because factor burden high taxes. Because dividend considered as shape income personal so that worn cost more tax tall compared with capital gains. If capital gain worn tax with rate lower than tax on dividends, then shares that own growth tall becomes more interesting. But otherwise if capital gain charged same tax with income on dividends, then profit capital gain Becomes reduced (Know Gregory Paulus, 2018). 


\section{International Journal of Current Science Research and Review}

ISSN: 2581-8341

Volume 05 Issue 02 February 2022

DOI: 10.47191/ijesrr/V5-i2-20, Impact Factor: 5.825

IJCSRR@ 2022

www.ijcsrr.org

\section{Pecking Order Theory}

The theory that describes a level in corporate fund search showing that company more choose use internal financing in finance invest and implement it as opportunity growth. Order funding according to theory this that is profit retained, debt, bonds and stocks new.

\section{Signaling Theory (Theory signal)}

According to (Bringham \& Houston, 2009) states that signaling Theory is something action taken Management Company that delivers instruction for investors about how management evaluate prospect company that. Theory this disclose that investors can differentiate among companies that have Mark tall with companies that have Mark low.

\section{Clientle Effect Theory}

Inside theory this there is two holder group share that is first group is group with holder shares like dividend Case this means holder share more like if company give high level of dividend payout ratio, the second group more like with receive capital gain thing this means holders share more like if company withhold part from profit clean.

\section{Connection Policy Debt with Profitability}

Policy Debt or Leverage is size Skill Company to pay whole obligation, meaning meant through percentage of capital used for pay debt. Financial leverage can give enhancement issuer is very important for give contribution great for issuer, and on the other hand can causing rise risk issuer in capital ownership becomes bankrupt height leverage show that company no solvable, meaning total the debt exceed of its total equity. High Debt to Equity Ratio Nilai take effect to acquisition Return on Equity that is causing acquisition Mark Return on Equity becomes low because should pay costs incurred consequence debt that. This thing in line with research conducted by (Gunde et al., 2017) that debt or leverage policies have influence to profitability.

\section{Connection Liquidity with Profitability}

Liquidity something company show company skills for pay off obligation period short and fund his efforts. This thing show that company invest amount big money on the side asset liquid. Put excess funds on assets will result in two different side. One of them is company more liquid, and others is that necessary source of funds used for invest income actually reserved for scope asset fluent so that manager company lost opportunity for get profit additional. According to Van Horne, and Wachowicz Liquidity Company compare backwards with profitability. The more liquid something company, more small ability to get profit. This thing in line with research conducted by (DM Dewi, 2016) and (Cahyani \& Badjra, 2017) that liquidity take effect to profitability.

\section{Connection Corporate Tax with Profitability}

Corporate Tax variable explains ability obligation taxation company Indonesian taxation is imposed rate tax progressive on income clean. The more tall payment corporate tax rate, then the more tall income company that. If the company's corporate tax high, then profit earned company is also high, so dividends distributed from part profit it is also high. This thing in line with research conducted by (Kusuma Pramana Robi, 2016) that Corporate Tax take effect to profitability.

\section{Connection Profitability with Policy Dividend}

Profitability is a company skill accept income through activity. Ratio profitability show how much effective and efficient by whole company managed. Return on Equity (ROE) can be represent stockholder refunds. Dividend including part from profit net received company, so dividend shared when company got profit. Dividend only could draw from profit net received. This thing influence total dividends paid moment pay dividends. The company produces inclined profit pay part big the profit as a dividend unit. Because more increase income earned, then the more high ability company for give dividend to stockholders. This thing in line with research conducted by (William et al., 2019) that profitability take effect significant to policy dividends.

\section{Connection Policy Debt with Policy Dividend}

According to Mustafa (2017: 142) if company with quick pay paid off debt owned, possibly dividend will low or income possible fixed and vice versa, if company no quick pay off debt, company could pay significant dividend from the profits it receives. Dividend can paid by company to stockholders with enough big if The benefits are also great. The more DER height shows total increasing debt tall so that will influence ability company share dividends, but high debt no obstruct company for Keep going share dividend to investors, remembering company should too notice interest capital owner. Obligation company for pay dividend no could 


\section{International Journal of Current Science Research and Review}

ISSN: 2581-8341

Volume 05 Issue 02 February 2022

DOI: 10.47191/ijesrr/V5-i2-20, Impact Factor: 5.825

IJCSRR@ 2022

www.ijcsrr.org

depending on the size small debt company even increase debt could Upgrade ability company pay dividend During use debt should always accompanied by with enhancement profit company. This thing in line with research conducted by (Sari \& Sudjarni, 2015) that policy debt take effect significant to policy dividends.

\section{Connection Liquidity with Policy Dividend}

Liquidity tall company show ability company in fulfil obligation period in short including pay dividends. This thing occur because company own asset fluent for share dividend to the holders stock. Capable company fulfil obligation period in short or in other words have level high liquidity signify that company in state good. Getting stronger position Liquidity Company more big dividends paid. This thing in line with research conducted by (William et al., 2019) that liquidity take effect positive and significant to policy dividends.

\section{Connection Corporate Tax with Policy Dividend}

Companies that have trend increase obligation tax, preference for payment dividends will also increase.

However according to (Demirgüneş, 2015), he state Corporate Tax there is influence bad to dividend payout ratio. This explained in accordance fact tax paid reduce total income company that can result in depreciation proportion income clean company to investors. So rise tax paid precisely the more small profitability that will obtained. So that will affect the amount dividend can provided by the company. This thing in line with research conducted by (Demirgüneş, 2015) that liquidity take effect positive and significant to policy dividends.

\section{Development Hypothesis}

Based on review the literature review and results study before, then formulated hypothesis is as following:

$\mathrm{H}_{1}$ : Policy debt, liquidity and corporate tax effect to profitability.

$\mathrm{H}_{2}$ : Policy debt take effect positive to profitability.

$\mathrm{H}_{3}$ : Liquidity take effect positive to profitability.

$\mathrm{H}_{4}$ : Corporate Tax has an effect positive to profitability.

$\mathrm{H}_{5}$ : Policy debt, liquidity and corporate tax effect to policy dividends.

$\mathrm{H}_{6}$ : Profitability take effect positive to policy dividends.

$\mathrm{H}_{7}$ : Policy debt no take effect to policy dividends.

$\mathrm{H}_{8}$ : Liquidity take effect negative to policy dividends.

$\mathrm{H}_{9}$ : Corporate Tax has an effect negative to policy dividends.

$\mathrm{H}_{10}$ : Profitability could mediate influence policy debt, liquidity and corporate tax to policy dividends.

\section{RESEARCH METHODS}

\section{Research Design}

Study this use method study quantitative. Study this is study causality that is is type study with characteristics problem in the form of connection cause and effect among two variable or more. Data collection with look report finance companies on the Indonesia Stock Exchange website. Shape data quantitative with data source is secondary. Population study is all trading companies listed on the Indonesia Stock Exchange for the period 2014-2019, namely totaling 50 companies. Retrieval technique sample use method Purposive Sampling. Sample study are 18 companies. Analysis used is Structural Equation Modeling (SEM) with using the AMOS (Analysis of Moment Structure) program.

\section{Definition Operational Variable}

Variable dependent in study this is Policy Dividends. Policy dividend projected with Dividend Payout Ratio with scale dummy measurement, where sharing company dividends above $40 \%$ are given value 1 and the company that shares dividends below $40 \%$ are given value 0 .

Variable Independent first that is policy debt. Policy debt projected with Debt to Equity Ratio compare total debt with owned capital company. Variable Independent second that is liquidity. Liquidity projected with Current Ratio compare total assets fluent with debt fluent company. Variable third that is Corporate Taxes. Measurement Corporate Tax with compare Tax Company with profit before tax. 


\section{International Journal of Current Science Research and Review}

ISSN: 2581-8341

Volume 05 Issue 02 February 2022

DOI: 10.47191/ijesrr/V5-i2-20, Impact Factor: 5.825

IJCSRR@ 2022

www.ijcsrr.org

Intervening variable in study this is projected profitability with Return on Equity (ROE). Measurement Return on Equity with compare profit clean after tax with total equity company.

\section{RESULTS AND DISCUSSION \\ Research Results \\ Descriptive Statistics}

Following this is results statistics from variable independent, that is policy debt (Debt to Equity Ratio), Liquidity (Current Ratio) and Corporate Tax. Intervening variables, namely profitability (Return on Equity) and variables dependent, that is policy dividend (Dividend Payout Ratio).

Table 1. Descriptive Test Results Statistics

\section{Descriptive Statistics}

\begin{tabular}{|l|r|r|r|r|r|}
\hline & \multicolumn{1}{|c|}{ N } & Minimum & Maximum & \multicolumn{1}{c|}{ Mean } & Std. Deviation \\
\hline KEB_HUTANG & 96 & .22 & 18.19 & 1.5914 & 2.00224 \\
LIKUIDITAS & 96 & .72 & 8.08 & 1.9371 & 1.40662 \\
CORP_TAX & 96 & .03 & .79 & .2299 & .08930 \\
DIVIDEN & 96 & .00 & 1.00 & .4167 & .49559 \\
PROFIT & 96 & .02 & 7.99 & .2664 & .82487 \\
ValidN (listwise) & 96 & & & & \\
\hline
\end{tabular}

Source: Processed Data

Variable Policy Debt own a minimum value of 0.22, namely PT Ace Hardware Indonesia, which means that from whole the company researched by PT Ace Hardware Indonesia has composition debt Lowest compared with the capital. Maximum value of 18.19, namely PT Matahari Department Store means that composition debt owned by PT Matahari Department Stores more big compared to their capital. The average value is 1.5914 with standard deviation 2.00224 . Variable liquidity own a minimum value of 0.72, namely PT Midi Utama Indonesia which means that from whole The company researched by PT Midi Utama Indonesia has ability assets the lowest smooth for cover obligation smoothly. Maximum value of 8.08, namely PT Ace Hardware Indonesia which means that PT Ace Hardware Indonesia has ability assets best smooth for cover obligation smoothly. The average value is 1.9371 and the standard deviation 1.40662 .

Variable Corporate Tax own the minimum value of 0.03 is PT Colorpark Indonesia which means that from whole the company researched by PT Colorpark Indonesia has percentage Lowest Tax Company. Maximum value of 0.79, namely PT Mitra Pinasthika Mustika it means that from whole the company under study PT Mitra Pinasthika Mustika own biggest percentage tax company. Average value 0.2299 and standard deviation 0.08930 . Variable policy dividend show a minimum value of 0 and a value of maximum 1 . The average value is 0.4167 or $42 \%$ which means that company sector share trading dividend above $40 \%$ as many as $42 \%$ or 40 companies and those who distribute dividend below $40 \%$ as much as $58 \%$ or 56 companies from total a sample of 96 companies. Whereas standard deviation 0.49559. Intervening variable profitability own a minimum value of 0.02 , namely PT Sumber Alfaria Trijaya it means that from whole the company researched by PT Sumber Alfaria Trijaya own level lowest return from business on all existing capital. Maximum value of 7.99, namely PT Matahari Department Store means from whole the company researched by PT Matahari Department Stores have level highest return from business on all existing capital. Average value 0.2664 and standard deviation of 0.82487 .

\section{Normality Test}

Test normality done for knowing level the normality of the data that has been researched. Normality test inspect the value of skewness in the data used only if skewness value is in the range between \pm 2.58 or between $-2.58<$ skewness $<+2.58$ then the data is said to be normal. Normality test results could see in table 2 below: 


\section{International Journal of Current Science Research and Review}

ISSN: 2581-8341

Volume 05 Issue 02 February 2022

DOI: 10.47191/ijesrr/V5-i2-20, Impact Factor: 5.825

IJCSRR@ 2022

Table 2. Normality Test

\begin{tabular}{|l|l|l|l|l|}
\hline Variable & skew & cr & kurtosis & cr \\
\hline CORP_TAX & .172 & .687 & 8,214 & 16,428 \\
\hline KEB_HUTANG & .173 & .693 & -.209 & -.418 \\
\hline LIQUIDITY & 2,335 & 10,539 & 7.156 & 14,312 \\
\hline PROFIT & 1,755 & 7.018 & 7.046 & 14,092 \\
\hline DIVIDEND & .338 & 1,352 & -1.886 & -3.771 \\
\hline Multivariate & & & 22,487 & 11,167 \\
\hline
\end{tabular}

Source: Processed Data, 2021

From table here are 2 results from normality test this showing skewness value between $-2.58<$ skewness $<+2.58$. From this could said data on research this already covers condition data normality is met, or could concluded that the data already normally distributed.

\section{Regression Model Feasibility Test (Goodness of Fit Test)}

Regression model feasibility test measure observed input validity or what is the input suitable with prediction of the proposed actual model (no there is data error).

Table 3. Goodness of Fit Test

$$
\begin{aligned}
& \text { Minimum was achieved Chi-square }=.000 \\
& \text { Degrees of freedom }=0
\end{aligned}
$$

Source: Processed Data

Based on table 4 results goodness of fit test this showing number Chi-square 0.000 . Researcher could conclude that this model in accordance or regression model suitable for analysis more carry on because no there is significant difference between both. Classification predictive and observed classification there is.

Test Hypothesis

Test hypothesis done well by simultaneous nor by partial. Calculation result contained in table 4 below this.

\begin{tabular}{|c|c|c|c|c|c|c|c|}
\hline \multicolumn{3}{|l|}{ Influence Variable } & Estimate & SE & CR & $\mathbf{P}$ & Information \\
\hline KEB_HUTANG & $\rightarrow$ & PROFIT & .427 & .132 & 3.249 & .001 & H2 Accepted \\
\hline LIQUIDITY & $\rightarrow$ & PROFIT & .220 & .080 & 2,747 & .006 & H3 Accepted \\
\hline CORP_TAX & $\rightarrow$ & PROFIT & .020 & .165 & .122 & .903 & H4 Not Accepted \\
\hline PROFIT & $\rightarrow$ & DIVIDEND & .239 & .060 & 3.950 & $* * *$ & H6 Accepted \\
\hline KEB_HUTANG & $\rightarrow$ & DIVIDEND & -.291 & .082 & -3.557 & $* * *$ & H7 Not Accepted \\
\hline LIQUIDITY & $\rightarrow$ & DIVIDEND & -.089 & .049 & -1.821 & .049 & H8 Accepted \\
\hline CORP_TAX & $\rightarrow$ & DIVIDEND & -.133 & .097 & -1.362 & .173 & H9 Not Accepted \\
\hline \multicolumn{5}{|c|}{$\begin{array}{l}\text { Squared Multiple Correlation } \\
\text { Profit: } 0.103 \\
\text { Dividend: } 0.215\end{array}$} & \multicolumn{3}{|c|}{$\begin{array}{l}\text { Minimum was achieved } \\
\text { Chi-square }=.000\end{array}$} \\
\hline
\end{tabular}

Table 4. Path Analysis Regression Weights. Test

Source: Processed Data 


\section{International Journal of Current Science Research and Review}

ISSN: 2581-8341

Volume 05 Issue 02 February 2022

DOI: 10.47191/ijesrr/V5-i2-20, Impact Factor: 5.825

IJCSRR@ 2022

Www.ijcsrr.org

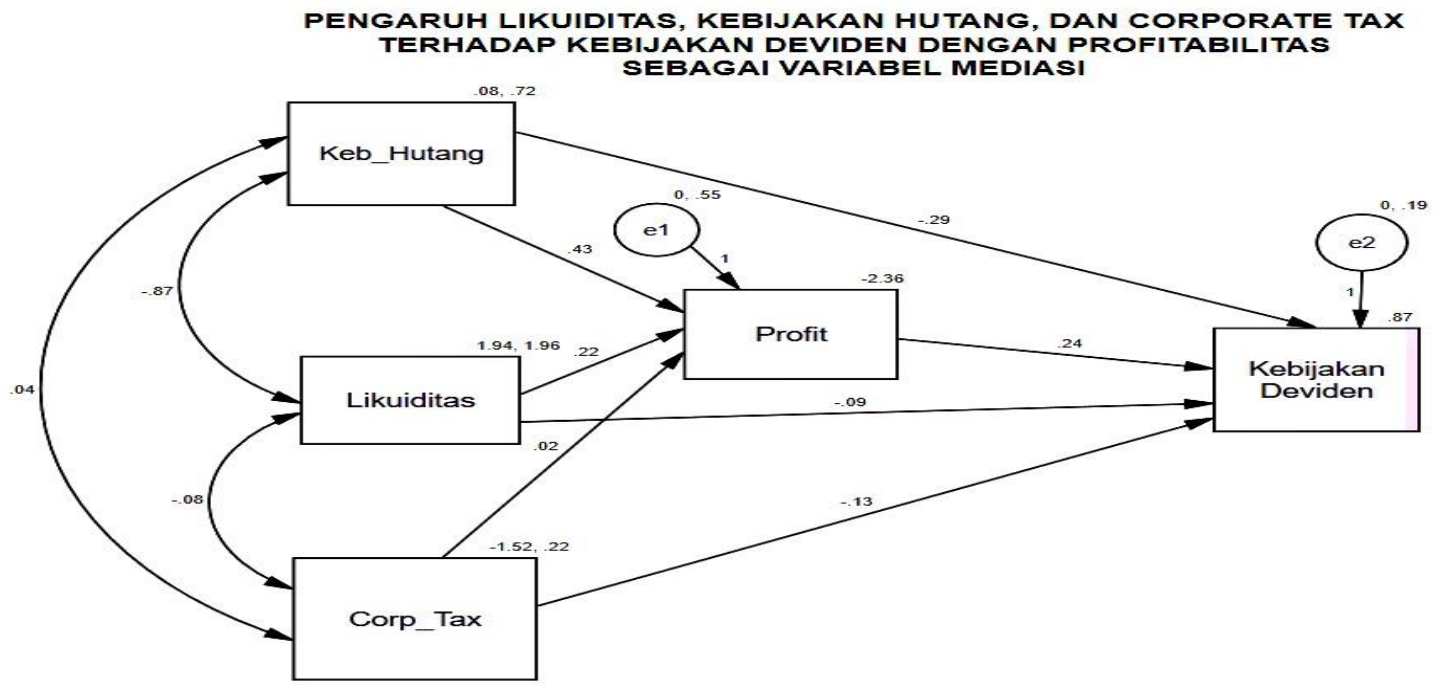

\section{RESEARCH RESULTS}

Intervening Test

Test results Path Analysis on research this show that results calculation intervening variable is shown in table 5 as following:

Table 5. Intervening Test

\begin{tabular}{|l|l|l|l|l|l|l|l|l|}
\hline Variable & \multicolumn{2}{|l|}{ KEB_HUTANG } & \multicolumn{2}{l|}{ LIQUIDITY } & \multicolumn{2}{l|}{ CORP_TAX } & PROFIT \\
& $\begin{array}{l}\text { Direct } \\
\text { Effects }\end{array}$ & $\begin{array}{l}\text { Indirect } \\
\text { Effects }\end{array}$ & $\begin{array}{l}\text { Direct } \\
\text { Effects }\end{array}$ & $\begin{array}{l}\text { Indirect } \\
\text { Effects }\end{array}$ & $\begin{array}{l}\text { Direct } \\
\text { Effects }\end{array}$ & $\begin{array}{l}\text { Indirect } \\
\text { Effects }\end{array}$ & $\begin{array}{l}\text { Direct } \\
\text { Effects }\end{array}$ & $\begin{array}{l}\text { Indirect } \\
\text { Effects }\end{array}$ \\
\hline PROFIT & $\mathbf{0 . 2 4 8}$ & $\mathbf{0 . 0 0 0}$ & $\mathbf{0 . 4 2 2}$ & $\mathbf{0 . 3 6 4}$ & $\mathbf{0 . 0 0 0}$ & $\mathbf{0 . 0 0 0}$ & $\mathbf{0 . 3 6 4}$ & $\mathbf{0 . 0 0 0}$ \\
\hline DIVIDEND & $\mathbf{- 0 . 5 1 4}$ & $\mathbf{0 . 8 3 8}$ & $\mathbf{0 . 2 9 2}$ & $\mathbf{0 . 4 1 5}$ & $\mathbf{0 . 6 4 8}$ & $\mathbf{0 . 5 9 2}$ & $\mathbf{0 . 4 1 5}$ & $\mathbf{0 . 6 4 8}$ \\
\hline
\end{tabular}

Source: Processed Data

Based on results the table 5 show that influence no direct more tall from influence straight to the relationship Among policy debt, liquidity and corporate tax on policy dividends, so that variable profitability working as intervention variable.

\section{DISCUSSION}

Influence Policy Debt, Liquidity and Corporate Tax to Profitability by Simultaneous

Policy Debt, Liquidity and Corporate Tax is a proper and appropriate regression model because all results from variable independent they have influence by simultaneous to profitability. The more tall policy debt company, liquidity and tax company, more many profit that will shared company to holder share in shape dividends and more many backup as profit detained, which will Upgrade profitability company and strengthen the company's capital for invest or support operation company in the future. This thing in accordance with theory signaling where Policy Debt, Liquidity and Corporate Tax could become signal for investors to see condition company so that capable reduce asymmetry Among investors with management.

\section{Influence Policy Debt to Profitability}

Policy Debt take effect positive to Profitability. Enhancement Debt to Equity Ratio will Upgrade Return on Equity which means company sector trading capable manage debt with good because contain something risk in shape financing relative interest height that makes company sector trading should can optimizing benefit cost her. This thing could interpreted that proportion between debt and company capital managed by effective in fund needs company. Increased debt to the company sector trading accompanied by with Ability Company for Upgrade profit. 


\section{International Journal of Current Science Research and Review}

ISSN: 2581-8341

\section{Volume 05 Issue 02 February 2022}

DOI: 10.47191/ijesrr/V5-i2-20, Impact Factor: 5.825

IJCSRR@ 2022

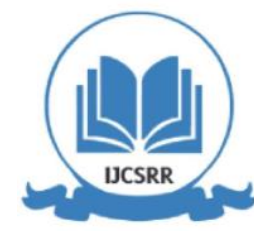

Study this in accordance with theory signal where could give signal that company sector trading capable manage by effective debt owned company for follow as well as produce profit company. However no in accordance with Pecking Order Theory which mentions the more tall profitability company so level the debt will the more low because inside Pecking Order Theory order priority for activity funding company is more prioritize internal funding sources, especially formerly before using external funds that is debt.

Study this in line with (Gunde et al., 2017) that policy debt take effect to profitability. However results study this no in line with research (Hasanah and Risky, 2020) which suggests that policy debt no take effect to profitability.

\section{Influence Liquidity to Profitability}

Liquidity take effect positive to Profitability. Enhancement Current Ratio will Upgrade Return on Equity which means company sector trading capable manage asset fluent with efficient and expected company could Keep going guard as well as Upgrade efficiency in utilization asset smoothly owned for Upgrade profitability company. Research results in accordance with theory signal that gives signal positive to investors that company sector trading capable manage asset fluent with efficient and expected company could keep going guard as well as Upgrade efficiency in utilization asset smoothly owned for Upgrade Profitability Company.

Study this in line with (Alicia, 2017) that liquidity take effect to profitability. However results study leave behind with results research conducted by (Melinda, 2017) which suggests that liquidity no take effect to profitability.

\section{Influence Corporate Tax to Profitability}

Corporate Tax no take effect to Profitability. Every enhancement Corporate Tax so not yet of course causing Return on Equity will follow as well as up or down. Company deposit tax to country as shape obey will obligation taxation. Besides that reason Corporate Tax no take effect to profitability company if seen from report finance company trading because management by periodic do evaluation on asset tax deferred and debt tax in period that. If profit fiscal no adequate for compensate part or all benefit asset tax deferred so will recognized in profit fiscal in the future come. This thing done as shape of planning strategy future tax company. Not maximal yet expansion of the existing tax base in Indonesia is also the cause of Corporate Tax is not take effect to profitability.

Research results this in line with research (Kusuma, 2018) that Corporate Tax does not take effect to profitability company. However study this leave behind with results research (Rehman and Takumi, 2012) which states that Corporate Tax has an effect to profitability.

\section{Policy Debt, Liquidity and Corporate Tax take effect to Policy Dividend by Simultaneous.}

Policy Debt, Liquidity and Corporate Tax take effect to Policy Dividend by Simultaneous. Regression model this is fit or worthy and right where results from all variable independent they have influence simultaneous to variable dependent that is policy dividends. The stronger variable Policy Debt, Liquidity and Corporate Tax owned company so will the more influence policy dividends given. This thing prove that variable Policy Debt, Liquidity and Corporate Tax could become pusher for company for share dividend because investors will invest if company the diligent share dividend as reciprocal form on investor funds invested to company.

\section{Influence Profitability to Policy Dividend}

Profitability take effect positive to policy dividends. Research results this in accordance with Signaling Theory and Bird in Hand Theory. Profitability rated Becomes a signal for investors to evaluate that company own good performance and will share dividend because company produce profit. Ability Company in get profitability could influence level payment dividends. With high profitability make company could share dividend to holder share because payment dividend only done if company get profit. Profits earned by the company is signal positive for investors to get expected dividends.

Theory second that is Bird in Hand theory (theory bird in hand) which says that investors will satisfied with return certain in shape dividend than no return certain such as capital gains. Connection Among profit and dividend is linear or correlated, because dividends paid on profit generated by the company could considered in management investment.

Study this in line with research conducted by Bawamenewi and Afriyeni (2019) that profitability take effect to policy dividends. However results study this no in line with research conducted by Siti Maulidah (2018) that profitability no take effect to policy dividends. 


\section{International Journal of Current Science Research and Review}

ISSN: 2581-8341

Volume 05 Issue 02 February 2022

DOI: 10.47191/ijesrr/V5-i2-20, Impact Factor: 5.825

IJCSRR@ 2022

www.ijcsrr.org

\section{Influence Policy Debt to Policy Dividend}

Policy debt take effect negative to policy dividends. For maintain capital, management more choose borrow for develop business company. Companies with level high debt so own increasing obligations big. This thing can impact on the distribution dividend Becomes smaller because profit earned company used for cover obligations owned company that delivers influence reduce income clean company, so will the more low ability company in pay dividends. Companies that have level big debt will more prioritize payment for pay off obligation to creditors in order to prevent bankruptcy because no can fulfil obligations, on the other hand if company own level low debt so company will more prioritize holder share with distribution dividends.

Research results this in line with results research conducted by Marvita (2016) that policy debt take effect negative to policy dividends. However results study this no in line with Melinda's research (2017) that policy debt no take effect to policy dividends.

\section{Influence Liquidity to Policy Dividend}

Liquidity take effect negative to policy dividends. Ratio liquidity influence Decision Company for pay dividend to holder shares in the sector trade. Position Liquidity Company is factor important in take into account distribution dividends. Holder share could evaluate Ability Company for produce profit in shape dividend on ratio smooth, because capable company liquidity own opportunity bigger for pay dividends and availability of funds. Research results show take effect negative that can be interpreted when company share dividend to holder share so ability liquidity company decreased.

Research results this in line with results research conducted by Teng Sauh Hwee (2019) and Nadia Ayu (2015) that liquidity take effect negative significant to policy dividends. However results study this no in line with research by Ida Ayu (2018) and Marvita (2016) that liquidity take effect positive significant to policy dividends.

\section{Influence Corporate Tax to Policy Dividend}

Corporate Tax no take effect to policy dividends. Corporate Tax no take effect to policy dividends on the company sector trade. Tax Company no Becomes factor important in determine quantity dividends that will shared. Tax Company is obligation to fulfilled company to the appropriate country with applicable law. With so, no there is connection among total tax paid company to countries with dividends paid to stockholders. Besides that, see from reports finance company policy dividend already set that company will share dividend to the holders share at least one time in a year as shape not quite enough answer to the holders share with give right in the form of dividend on shares that have been placed.

Research results this in line with results research conducted by Erviliana (2014) and Pancawati (2013) that Corporate Tax no take effect to policy dividends. However results study this no in line with research by Gayatri (2015) and Rehman and Takumi (2012) that Corporate Tax take effect to policy dividends.

Profitability could mediate influence Policy Debt, Liquidity and Corporate Tax To Policy Dividend Profitability in study this working as intervening variables that can be mediate variable independent Policy Debt, Liquidity and Corporate Tax with variable dependent that is Policy Dividends. Ability Company for reach profitability could influence big dividends paid. Dividend paid only when company get profit, so could share to holder stock. Increase debt companies in the sector trading upgrade Profitability Company. Companies can by effective manage debt they for participate in produce profit. The size debt no as well as immediately reduce Profit Company or company cash position. Managed debt with good could produce more much money than spent for pay flower to creditor. Sector company trading capable manage asset fluent with efficient in utilise asset smoothly owned for Upgrade profitability company. Position liquidity something company is factor important in count payment dividend because Liquidity Company reflect availability of company funds for payment dividends that are not hindered by debt period short. With look variable corporate tax investors can take into account Profitability earned company. If Corporate Tax tall so resulting profitability company can go up or down, but in study this variable Corporate Tax no take effect to profitability company because enhancement tax from year to year no experience significant change as well as not yet maximum expansion of the existing tax base in Indonesia. Policy dividend no look big small tax paid company every year. But with look amount of tax paid could interpreted that company the capable pay tax to the country and existence cash availability for pay dividend to holder stock.

\section{FINDING STUDY}

In study this there are 4 accepted hypotheses. First one that is Policy Debt (DER) has an effect to Profitability (ROE). Study this in accordance with theory signal where could give signal that company sector trading capable manage by effective debt owned 


\section{International Journal of Current Science Research and Review}

ISSN: 2581-8341

\section{Volume 05 Issue 02 February 2022}

DOI: 10.47191/ijesrr/V5-i2-20, Impact Factor: 5.825

IJCSRR@ 2022

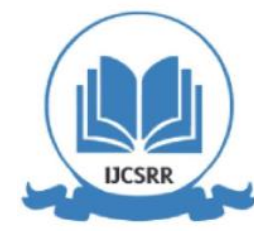

www.ijesrr.org

company for follow as well as produce profit company. However no in accordance with Pecking Order Theory which mentions the more tall profitability company so level the debt will the more low because inside Pecking Order Theory order priority for activity funding company is more prioritize internal funding sources, especially formerly before using external funds that is debt. Second Liquidity (CR) has an effect to Profitability (ROE). Research results the in accordance with theory signal that gives signal positive to investors that company trading capable manage asset fluent with efficient and expected company could Keep going guard as well as Upgrade efficiency in utilization asset smoothly owned for Upgrade profitability company. Third Profitability (ROE) has an effect to Policy Dividend (DPR). Research results the in accordance with Signaling Theory and Bird in Hand Theory. Based on theory signal Profitability rated Becomes a signal for investors to evaluate that company own good performance and will share dividend because company get profit. Ability Company in get profitability could influence level payment dividends. With high profitability make company could share dividend to holder share because payment dividend only done if company get profit. Theory second that is Bird in Hand Theory (theory bird in hand) which says that investors will like with fixed income that is in the form of dividend than unpaid income certain as capital gains. Connection Among linear profit and dividend or each other relate because dividends given on the profit earned by the company can becomes ingredient consideration for manage investment. Fourth Liquidity (CR) has an effect to Policy Dividend (DPR). Position Liquidity Company is factor important in take into account distribution dividends. With look Current Ratio of the holders share can evaluate how far the company could give payback results in the form of dividend because company that can guard liquidity his finances have opportunity more big or availability of funds for share dividend because no burdened with obligation period in short.

Profitability could mediate influence policy debt, liquidity and corporate tax to policy dividends. Ability Company in get profitability could influence level payment dividends. With high profitability make company could share dividend to holder share because payment dividend only done if company get profit. Increase in debt can push company in payment dividend during the debt could give optimal profit and load flower can covered by the profits generated. Sector company trading capable manage as set fluent with efficient in utilise asset smoothly owned for Upgrade profitability company. Position Liquidity Company is factor important in take into account distribution dividend because with look liquidity company could look availability of Funds Company for share dividends that are not blocked with obligation period in short. With look Corporate Tax variable investors can take into account Profitability earned company. If Corporate Tax is high so resulting profitability company can go up or down. Policy dividend no look big small tax paid company every year. But with look amount of tax paid could interpreted that company the capable pay tax to the country and existence cash availability for pay dividend to holder stock .

\section{CONCLUSION}

Based on results data analysis and discussion that has been put forward could concluded as following: Variable Policy Debt, Liquidity and Corporate Tax have an effect to Profitability by simultaneous. Variable Policy Debt take effect positive to Profitability. Variable Liquidity take effect positive to Profitability. Corporate Tax variable is not take effect to Profitability. Variable Policy Debt, Liquidity and Corporate Tax have an effect to Policy Dividend by simultaneous. Variable Profitability take effect positive to Policy Dividends. Variable Policy Debt take effect negative to Policy Dividends. Variable Liquidity take effect negative to Policy Dividends. Variable Corporate Tax no take effect to Policy Dividends. Variable Profitability could mediate influence Policy Debt, Liquidity and Corporate Tax to Policy Dividends.

\section{RECOMMENDATION}

Recommendation from results study is the first, for companies that want get capital from investors better company could show performance the best with results profit generated every period consistently increasing profit every period of course will make investors want embed capital in the company that. Based on results study proven that profitability take effect to policy dividends. This thing could concluded that company should could Upgrade profit so you can share dividend to investors and make investors interested for Keep going embed capital in the company sector trade. Second, for potential investors who will embed capital and investors who have embed capital in the company sector trading should notice variable Policy Debt, Liquidity and Profitability because proven take effect to policy dividends. Third, for researcher next expected could add more many variables that can be influence policy dividends, get add period study with more many again researched and expected year researcher next could add sample companies in various sector so that the research produced could more accurate the result. 


\section{International Journal of Current Science Research and Review}

ISSN: 2581-8341

Volume 05 Issue 02 February 2022

DOI: 10.47191/ijesrr/V5-i2-20, Impact Factor: 5.825

IJCSRR @ 2022

www.ijesrr.org

\section{IBLIOGRAPHY}

1. Adhikara, Arrozi, MF, Maslichah, Nur Diana, M. Basjir, 2022, Organizational Performance in Environmental Uncertainty on the Indonesian Healthcare Industry: A Path Analysis, Academic Journal of Interdisciplinary Studies, Vol 11, No 2, ISSN: 2281-4612

2. Ahyar, H., Maret, US, Andriani, H., Sukmana, DJ, Mada, UG, Hardani, S.Pd., MS, Nur Hikmatul Auliya, GCB, Helmina Andriani, MS, Fardani, RA, Ustiawaty, J., Utami, EF, Sukmana, DJ, \& Istiqomah, RR (2020). Book Method Study Qualitative \& Quantitative (Issue March).

3. Alicia, DD (2017). Influence Liquidity To Profitability of Cement Sub - Sector Companies Listed on the Indonesia Stock Exchange for the 2011-2015 Period. Student Online Journal (JOM) Field Accounting, 2(2), 1-11.

4. Amidu, M., \& Abor, J. (2006). Determinants of dividend payout ratios in Ghana. Journal of Risk Finance,

5. 7(2), 136-145. https://doi.org/10.1108/15265940610648580

6. Ano, RR, Pure, S., \& Rate, P. Van. (2014). Influence Liquidity And Profitability Against Dividend Payout Ratio in Subsector Banks Listed on the Indonesia Stock Exchange for the Period 20092013. Journal Research Economics, Management, Business And Accounting, 2(3), 884-894.

7. Bringham, EF, \& Houston, JF (2009). Management Finance. 1-100. https://doi.org/10.31227/osf.io/kdtfj

8. Cahyani, NLAP, \& Badjra, IB (2017). Effect of Leverage and Liquidity To Policy Dividend With Profitability As Intervening Variables on the IDX. None, 6(10), 254591.

9. Demirgüneş, K. (2015). Determinants of target dividend payout ratio: A panel autoregressive distributed lag analysis. International Journal of Economics and Financial Issues, 5(2), 418-426.

10. Dewi, DM (2016). Influence Liquidity, Leverage, Firm Size Against Policy Dividend Cash With Profitability As Intervening Variables. Journal Business And Economics (JBE), 23(1), 12-19.

11. Dewi, IAPP, \& Sedana, IBP (2018). Influencing Factors Policy Dividends on Manufacturing Companies on the Indonesia Stock Exchange. 7(7), 3623-3652.

12. Ginting, S. (2018). Influence Liquidity, Profitability, and Leverage Against Policy Dividends on LQ45 Companies Listed on the Indonesia Stock Exchange for the Period 2012-2016. 8, 195-204.

13. Gunde, YM, Murni, S., \& Rogi, MH (2017). Analysis Effect of Leverage on Profitability in Food and Beverages Sub Industry Manufacturing Companies Listed on the Stock Exchange (2012-2015

14. Period). EMBA Journal: Journal Research Economics, Management, Business And Accounting, 5(3). https://doi.org/10.35794/emba.v5i3.18382

15. Hardiningsih, P., \& Oktaviani, RM (2013). Determinant Policy Dividend Sector Manufacturing (Pecking Order Hypothesis Perspective and Agency Theory). Determinant Policy Dividend Sector Manufacturing (Pecking Order Hypothesis And Agency Theory Perspective), 751-763.

16. Hasana, R., Mardani, RM, \& Wahono, B. (2017). Effect of Free Cash Flow, Profitability, Liquidity and Leverage on Policy Dividends on Foof And Beverage Companies Listed on the Indonesia Stock Exchange (IDX) for the 2014-2016 period. EJournal Research Management, 7(12), 88-102.

17. Mahesti, FS, Purbandari, T., \& Mujilan. (2013). Factors Affecting the Dividend Payout Ratio (DPR) in Manufacturing Companies Listed on the Stock Exchange in 2009 - 2011. 01(02), 13-21.

18. Monika, NGAPD, \& Sudjarni, LK (2018). Influence Liquidity, Profitability and Leverage Against Policy Dividends on Manufacturing Companies on the Indonesia Stock Exchange. 7(2), 905-932.

19. Mustafa. 2017. Management Finance. Yogyakarta: Publisher Andi.

20. Nadia Soraya Puteri Meutia, \& Kristianti, FT (2015). Influence Profitability, Liquidity, and Leverage on Dividend Payout Ratio in the Property and Real Estate Sub - Sector Listed on the INDONESIA STOCK EXCHANGE 2010-2014. 2(3), 2015.

21. Nuzula, F. (2018). Effect of Free Cash Flow, Institutional Ownership, Life Cycle Stage on Policy Dividends on Manufacturing Companies Listed on the IDX. Economics, 121.

22. Officer, AAGAN, \& Wiksuana, IGB (2018). Influence Profitability And Growth Asset To Policy Dividends and Firm Value. 7(7), 3767-3796. 


\section{International Journal of Current Science Research and Review}

ISSN: 2581-8341

Volume 05 Issue 02 February 2022

DOI: 10.47191/ijesrr/V5-i2-20, Impact Factor: 5.825

IJCSRR@ 2022

www.ijjesrr.org

23. Prasetyo, FN, \& Sampurno, RD (2013). Analysis Effect of Net Profit Margin, Current Ratio, Debt to Equity Ratio, Company's Growth, Firm Size, and Collateralizable Assets on Dividend Payout Ratio. 2, 1-12.

24. Pratiwi, RD, Siswanto , E., \& Istanti , LN (2016). Effect of Return On Equity, Debt to Equity Ratio, Current Ratio, and Firm Size on Price Earning Ratio of Manufacturing Companies Listed on the IDX. Journal Economy Business, 21(Thesis. Study Program Management, Faculty Economics, Yogyakarta State University), 136.

25. Puspita, F. (2009). Analysis influencing factors policy.

26. Refra, E., \& Wdiastuti, MC (2014). Effect of Profitability, Firm Size, Tax, Investment Opportunities, Life Cycle Stage on Dividend Policy in Industry Manufacturing in Indonesia. Management EJournal Faculty Trisakti University Economics, 1(2), 84-105.

27. Rehman, A., \& Takumi, H. (2012). Determinants of Dividend Payout Ratio: Evidence From Karachi Stock Exchange (KSE). Journal of Contemporary Issues in Business Research, 1(1), 20-27.

28. Sari, KAN, \& Sudjarni, LK (2015). Influence Liquidity, Leverage, Company Growth, And Profitability To Policy Dividends on Manufacturing Companies on the IDX Komang. 4(10), 3346-3374.

29. Sulaiman, H., \& Sumani. (2016). Analysis Influence Liquidity, Leverage, Activity, Profitability, and Growth Against Policy Dividend Listed Issuers on the LQ-45 Index 2011-2013 Period. Journal Management, 13(2), 179-197.

30. Know Gregory Paul. (2018). antecedent policy Dividends and Its Implications on Firm Value (MC Dr. Anik Yuesti, SE. (ed.)). CV. Noah Aletheia.

31. Utami, GK, \& Robin. (2015). Analysis Influencing Factors Ratio Payment Dividends on Companies Listed on the Indonesia Stock Exchange. Journal Management, 15(1), 41-58.

32. Weygandt, JJ, Kimmel, PD, \& Kieso, DE (2013). Financial Accounting.

33. William, Stephani, Vera, Supantri, D., Wynne, \& Prasetya, D. (2019). Influence Ratio Solvency, Ratio Profitability, Liquidity and Earnings Per Share Against Policy Dividends on Consumer Goods Companies Listed on the Indonesia Stock Exchange (IDX) for the 2013-2017 period. 14(1), 1- 10.

34. Wispandono, M. (2019). Management Finance. https://doi.org/10.31227/osf.io/kdtfj

35. Atalya Puspa. (https://mediaindonesia.com/read/detail/245934-24-corporate-go-public-swastamendominat). 9 July 2019. 24 Companies Go Public Private Dominate, accessed 22 September 2020.

36. Syahrizal print. (https://www.cnbcindonesia.com/market/20200409094615-17-150794/3-emiten-barulisting-di-beisaham-melesat-to-35). April 9, 2020. 3 Issuers Newly Listed on IDX, Stocks Soar up to 35\%, accessed 22 September 2020.

37. Ika Puspitasari. (https://investasi.kontan.co.id/news/bei-masih-ada-6-corporate-planning-ipo-di-2020). 21 September 2020. IDX: There are still 6 companies planning an IPO in 2020, accessed 22 September 2020.

38. M. Nurhadi Pratomo. (https://market.bisnis.com/read/20200716/7/1266923/bei-sum-ipo-indonesiaterbanyak-di-asiatenggara). 16 July 2020. IDX: The Most Number of Indonesian IPOs in Southeast Asia, accessed 22 September 2020.

39. Ika Puspitasari . (https://investasi.kontan.co.id/news/per-mei-2020-bei-cat-percepat-investor-pasarmodal-sebesar-13). 26 June 2020. As of May 2020, IDX notes capital market investor growth of 13\%, accessed 22 September 2020.

40. Mang Amsi. (https://www.syariahsaham.com/2017/08/link-unduhan-List-dividen-tunai-2001.html). April 3 , 2020. List of Dividends Cash 2001-2020, accessed 28 September 2020.

41. Edison Sutan Kayo. (https://www.sahamok.com/emiten/List-emiten-2014/). January 4, 2015. List of Issuers 2014, accessed 28 September 2020.

42. Edison Sutan Kayo. (https://www.sahamok.com/emiten/List-emiten-saham-

43. 2015/\#: :text=Daftar\%20emiten\%20saham\%20yang\%20tercatat,Efek\%20Indonesia\%20ada\%20525\%20companies). January 7, 2017. List of Issuers of Shares 2015, accessed 28 September 2020.

44. Edison Sutan Kayo. (https://www.sahamok.com/emiten/List-emiten-saham-2016/\#: :text=Daftar\%20emiten\% 20saham \%20yang\%20tercatat,Efek\%20Indonesia\%20ada\%20539\%20companies). January 7, 2017. List of Issuers of Shares 2016 , accessed 28 September 2020.

45. Ahmad Bi Afriyadi. (https://finance.detik.com/bursa-dan-valas/d-4362316/lid-tahun-bei-pamer-sumemiten-barubreaking-rekor). 28 December 2018. Closed Year, IDX Shows Amount issuer New Broken Records, accessed 28 September 2020 . 


\section{International Journal of Current Science Research and Review}

ISSN: 2581-8341

Volume 05 Issue 02 February 2022

DOI: 10.47191/ijesrr/V5-i2-20, Impact Factor: 5.825

IJCSRR@ 2022

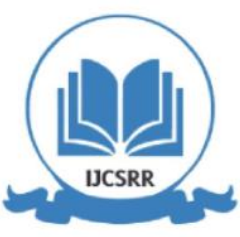

WwW.ijcsrr.org

46. Education Team. (https://www.edusaham.com/2019/02/data-capitalization-pasar-2017-all-emiten-dibursa- Efekindonesia.html). February 13, 2019. Market Capitalization Data 2017 All Issuers on the Indonesia Stock Exchange, accessed 28 September 2020.

47. GiriHartomo. (https://idxchannel.okezone.com/read/2019/12/31/278/2147766/fact-pasar-modal-2019bei-ketangan-55emiten-baru). 31 December 2019. Capital Market Facts 2019, IDX Arrival of 55 Issuers New, accessed 28 September 2020.

48. Bi Ayuningtyas. (https://www.cnbcindonesia.com/market/20190529094446-17-75692/13-emiten-bagidividen-hari-ini-rp21-t-apa-juaranya/). 29 May 2019. 13 Issuers For Today's Dividend Rp 21 T, Who The winner, accessed 12 January 2019.

49. Rina Anggraeni. (https://ekbis.sindonews.com/berita/1404586/178/ini-alasan-mapa-not-bagikandividen). May $16,2019$. This MAPA Reason No Share Dividend, accessed 12 January 2019.

50. Lynda Hasibuan. (https://www.cnbcindonesia.com/lifestyle/20190125124753-33-52350/gerai-ritel-riberguguran-hasilkonsumen-hijrah-ke-online). January 25, 2019. Outlet Indonesian Retail Falls, As a result Consumers Moving to Online? accessed 12 January 2019.

51. Constitution Number 28 of 2007. Directorate General tax. (https://pajak.go.id/id/undang-undang-28tahun-2007), accessed 22 October 2020.

Cite this Article: Katryn Trie Wicak Ikhsani, MF. Arrozi Adhikara (2022). The Effect of Debt, Liquidity and Corporate Tax Policy on Dividend Policy with Profitability as Intervening Variables in Trading Companies Listed on the Indonesia Stock Exchange for the 2014-2019. International Journal of Current Science Research and Review, 5(2), 468-480 